\title{
Implementation of LCM (Linear Congruent Method) Method in Region Song Game
}

\author{
Addinul Arfansyah Harahap, Nelly Astuti Hasibuan \\ Department of Computer Science, Universitas Budi Darma, North Sumatra, Indonesia \\ Email: addinularhar@gmail.com
}

\begin{abstract}
The Regional Song Game is a game that educates players to hone the ability of knowledge about folk songs in the form of questions given the Regional Song game. With the game Regional Songs, players can expand the ability of players about the knowledge of regional songs. Aside from being a means of entertainment, games can also be an exciting learning medium and do not make players bored, so it becomes a pleasant learning atmosphere. The linear congruent method (LCM) is a random number generator method that is widely used by computer programs. The application of the Linear Congruent Method (LCM) in the Regional Song game is intended to randomize the questions that will be displayed by the Regional Song game. Regional Songs Game is an application designed to provide insights about folk songs for the players. This game aims to reintroduce folk songs to the people lost by the ages.
\end{abstract}

Keywords: Linear Congruent Method, Game, Song, Area.

\section{INTRODUCTION}

Indonesia is a country that has various types of folk songs that are spread throughout the territory of Indonesia. But the Regional Song was forgotten because people preferred songs that hit like Pop Songs. The lack of media or means to popularize folk songs is one of the causes of the children's lack of understanding of folk songs. Regional song or Regional Song, is a song or music that comes from a particular area and becomes popular sung both by the people of the area and other people. Regional songs are similar to the national anthem, but their status is only regional. Regional songs usually have lyrics in accordance with their respective regional languages. Artificial intelligence (Artificail Intelligence) is a part of the field of science that can mimic the behavior and functions of the human brain. This has led to the birth of various technologies that can be said to be intelligent, especially in the development of this modern game. With this Artificial Intelligence based game, players are involved to hone and arrange strategies to defeat the Artificial Intelligance.

\section{THEORY}

\subsection{Artificial Intelligence}

Artificial intelligence comes from the English language "Artificial Intelligence" or abbreviation AI, namely Intelligence is an adjective that means smart, while Artificial means artificial. Artificial intelligence is a machine that is able to think, weigh the actions taken, and be able to take decisions as done by humans. This system can mimic the functions of the human brain, such as language understanding, thought knowledge, problem solving and so on. Artificial intelligence is more permanent and its ability will never change as long as the program is not changed by the programmer. Artificial Intelligence (Artificial Intelligence) is a field of science that is often used for approaches that are essential for solving a problem with a different field of Artificial Intelligence. The techniques in artificial intelligence are:

1. Game

Is a form of entertainment that is often used as a refreshing mind from fatigue caused by activities and routines.

2. Fuzzy Logic

A method of Artificial Intelligence that is widely available in electronic devices and robotics. Where electronic devices or robotics are able to think and behave like humans.

3. Speech Recognition

A method of Artificial Intelligence that is widely used to recognize human speech by matching it with preprogrammed references.

4. Computer Vision

An Artificial Intelligence method that allows a computer system to recognize images as input. An example is recognizing and reading the text in the picture.

5. Expert System 
That is a method of Artificial Intelligence that is useful for mimicking the way of thinking and reasoning of an expert in making decisions based on the situation. With the Expert System, a user can consult a computer, as if it were consulted directly to an expert.

6. General Probem Solving

Namely an Artificial Intelligence method that deals with solving a problem to a situation that will be solved by a computer. Usually the problem will be solved by trial and error until a solution of a problem is found. [2].

\subsection{Game}

Is that a game? maybe this one word is a word that almost all humans on earth know what game is. Although different tribes and nationalities but when talking about games they certainly know that the game is a game.

The game has never known the age and social status, all people may enjoy the game, young and old, rich-poor, and men and women all can enjoy the game. Now in modern times there are many media. There are smartphones, tabs, tablets, portable games and other game machines.

Games are voluntary interactive activities, where one or more players follow rules that limit their behavior, imposing artificial conflicts that end with measurable results. The beginning of the formal analysis of game theory was duopoly learning from Antoine Cournot in 1838. Mathematician Emile Borel suggested a formal theory of the game in 1921, which was followed up by mathematician John Von Neumann in 1928 in "Theory of Parlor Games". Some of these theories provide many basic terminology and configuration problems that are still used today. [3].

\subsection{Linear Congruent Method (LCM) Method}

Linear Congruent Method is a random number generator method that is widely used in computer programs. Random numbers are a quantity in modeling and simulation techniques. In modeling and simulation a lot of using random numbers as a quantity to get the solution of a simulation problem. To get numbers that are truly random, manually can be done by lottery, social gathering or using a roullete machine. But computationally, this is difficult. Caused that the computer is a deterministic machine, while random numbers appear as probabilistic events. The only way to get random numbers is to use a pseudo random generator, where random numbers are obtained deterministically (arithmetic).

Linear Congruet Method is very widely used to generate random numbers $\mathbf{x 1 ,} \mathbf{x 2}, \ldots ., \mathbf{x n}$ which are worth $[0, \mathrm{~m}]$ by utilizing the previous value. To generate random numbers to $n+1(x n+1)$ with the linear congruent method defined:

\section{$\mathrm{Xn}+1=(\operatorname{axn}+\mathbf{c}) \bmod \mathbf{m}$}

Where: $\mathrm{xn}$ is a random number to $\mathrm{n}$

$\mathrm{A}$ and $\mathrm{c}$ are LCM constants

$\mathrm{m}$ is the maximum limit of random numbers

Linear Congruent Method will be repeated at a certain time period or after several times generation, this is one of the characteristics of this method, and pseudo random generators in general. Determination of LCM constants $(\mathrm{a}, \mathrm{c}$ and $\mathrm{m}$ ) is very good for determining whether random numbers are obtained in the sense of obtaining random numbers as if random numbers did not occur. Generates random numbers 8 times with :

$$
\begin{aligned}
& \mathrm{a}=2, \mathrm{c}=7, \mathrm{~m}=10 \operatorname{dan} \mathrm{x}(0)=2 \\
& \mathrm{x}(1)=(2(2)+7) \bmod 10=1 \\
& \mathrm{x}(2)=(2(1)+7) \bmod 10=9 \\
& \mathrm{x}(3)=(2(9)+7) \bmod 10=5 \\
& \mathrm{x}(4)=(2(5)+7) \bmod 10=7 \\
& \mathrm{x}(5)=(2(7)+7) \bmod 10=1 \\
& \mathrm{x}(6)=(2(1)+7) \bmod 10=9 \\
& \mathrm{x}(7)=(2(9)+7) \bmod 10=5 \\
& \mathrm{x}(8)=(2(2)+7) \bmod 10=7
\end{aligned}
$$

Random numbers generated are: 1, 9, 5, 7, 1, 9, 5, 7. Periodic repetition occurs. Repetition occurs at a certain time period or after a number of times of generation, this is one of the characteristics of this method, and pseudo random generators in general. Determination of the Linear Congruent Method constant ( $\mathrm{a}, \mathrm{c}$ and $\mathrm{m}$ ) determines whether or not random numbers are obtained in the sense of obtaining random numbers as if repetition does not occur. [7].

\section{RESULT AND DISCUSSION}


The Regional Song Game was created to add to your insight about folk songs and the history of the songs. This game is a quiz (question), so from there the author made this game to hone the ability of players and measure the extent to which the player's knowledge can answer the questions given by the Regional Song game. With this game players can broaden their horizons and knowledge about songs in the Indonesian region and get used to interacting with computers. Creating a pleasant learning atmosphere is one of the learning techniques. Games as one of the things that can make players feel happy, so it is effective to be a learning medium that is challenging, exciting and relaxed.

The structure of the Regional Song game includes several stages, here are the stages of the Regional Song game, namely:

1. Intro.

At this stage consists of several buttons namely: Start, Hint and Exit. Each button has its own function, for example the Start button which functions to continue the game, the Hint Function button as a game guide or game steps so that the player can win the Regional Song game.

2. Initial Level (Easy).

At this initial level (easy) players will compete with artificial intelligence, where players will face several questions in the form of multiple choices. This level has 10 questions and each question has 10 points, which points will determine the player to proceed to the next level. Players must get at least 80 points to proceed to the next level if the player can answer all questions then the player is entitled to get an additional point of 20 points, and if less than 80 points, the player cannot continue to the next level.

3. Medium Level

Where at this level the problem is in the form of song texts, where the text of the song is irregular, the player is required to arrange the stanzas for stanzas correctly so that they form the correct stanzas. At this level there are 15 question questions in which each question has 25 points and the player must answer at least 12 questions out of these 15 questions to continue to the final level, the Hard Level.

4. Hard level

Where at this level is the last part in this game is the most difficult part of the game from the previous level. In this level the player must guess the title of the song by listening to the music intro only and only given 10 seconds to listen to the intro. Where this round consists of 20 questions and each question in this round is worth 30 points in 1 question and to complete this level the player must pass the point limit specified in this Regional Song game. Where the points will be added up from all levels and must reach or exceed the specified points to complete this game.

\subsection{Application of the Linear Congruent Method (LCM)}

Linear Congruent Method (LCM) method is a random number generator method that is widely used by computer programs. Linear Congruent Method (LCM) is used to determine the position of hiding data, where the placement of positions is done randomly. Song Nusantara game is a learning game and is played by one person where the player must answer all questions that are randomized until the game is finished using the Linear Congruent Method (LCM). Song Nusantara game has several stages where each round has several questions that must be answered by the player. So that the questions displayed are not the same, the writer uses the Linear Congruent Method (LCM) which functions as a scrambler for the questions displayed in the Nusantara Song game over and over or not at the first time it is played. The Linear Congruent Method (LCM) method is very widely used to generate random numbers $x 1, x 2, \ldots, x n$ which are worth $[0, m] n+1(x n+1)$ with the linear congruent method (LCM) method.

Linear Congruent Method method will occur repetition in a certain time period or eleven times generation, this is one of the properties of this method, and pseudo random generators in general. The determination of LCM constants ( $\mathrm{a}, \mathrm{c}$ and $\mathrm{m}$ ) determines whether or not random numbers are obtained in the sense of getting random numbers as if random numbers did not occur.

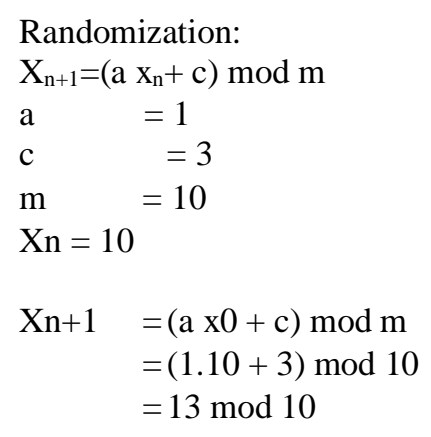


The IJICS (International Journal of Informatics and Computer Science) Vol 4 No 2, September 2020

ISSN 2548-8384 (online) ISSN 2548-8449 (print)

Page $57-62$

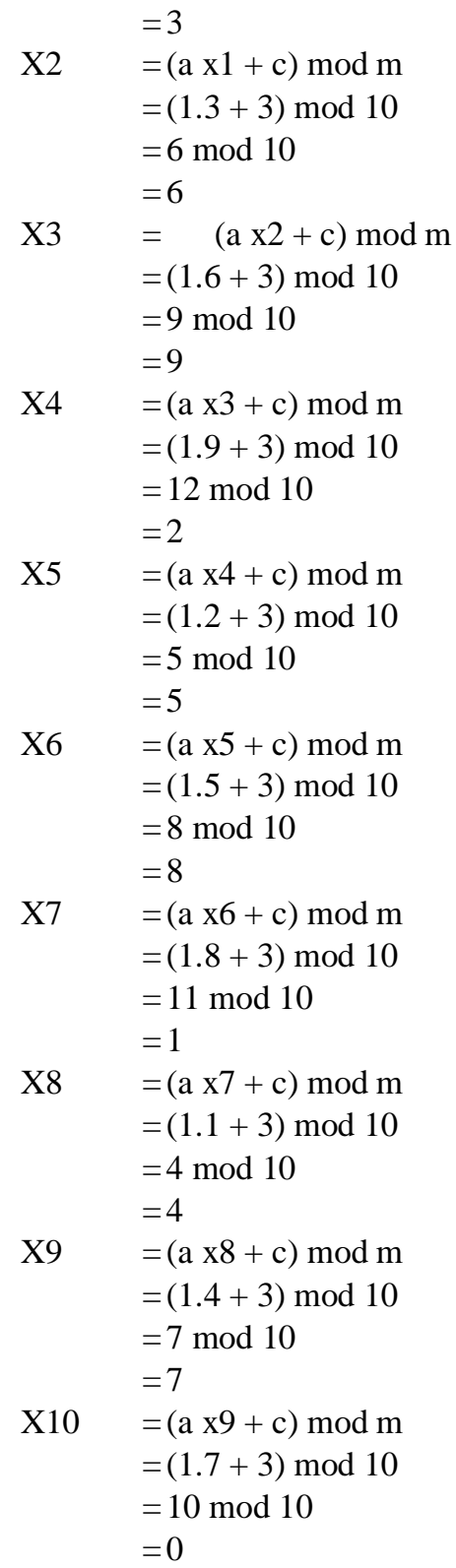

Examples of randomization of questions from the Song Nusantara game using the Linear Congruent Method (LCM) can be seen from the table below.

Table 1. Randomization table question game Regional Song

\begin{tabular}{clc}
\hline $\begin{array}{c}\text { Kode_pertanyaaan } \\
\text { LV1 }\end{array}$ & \multicolumn{1}{c}{ Pertanyaan } & $\begin{array}{c}\text { Linear congruent } \\
\text { method }\end{array}$ \\
\hline L100 & Lagu butet bersal dari daerah ? & 3 \\
L101 & Lagu pinang Muda berasal dari provinsi ? & 6 \\
L102 & Lagu Ampar-ampar Pisang Berasal dari kalimantan bagian ? & 9 \\
L103 & Apa makna lagu Cik-Cik Periuk ? & 2 \\
L104 & Natikui ....... narande Lombok, isi titik tersebut dengan lirik & 5 \\
& lagu yang benar ? & 8 \\
L105 & Siapa pencipta Lagu Tumpi wayu ? & 1 \\
L106 & Lagu bunga cempa berasal dari daerah ? & 4 \\
L107 & Kata Apuse kokon dao berarti ? & 7 \\
L108 & Seniman pencipta lagu Apuse berasal dari kota ? & 0 \\
L109 & Siapa pencipta lagu lagu Gundhul Pacul ? & \\
\hline
\end{tabular}


The IJICS (International Journal of Informatics and Computer Science) Vol 4 No 2, September 2020

ISSN 2548-8384 (online) ISSN 2548-8449 (print)

Page $57-62$

\section{IMPLEMENTATION}

The main menu form contains the main display on the Regional Song Game and contains three buttons namely "Play", "Hint", "Exit".

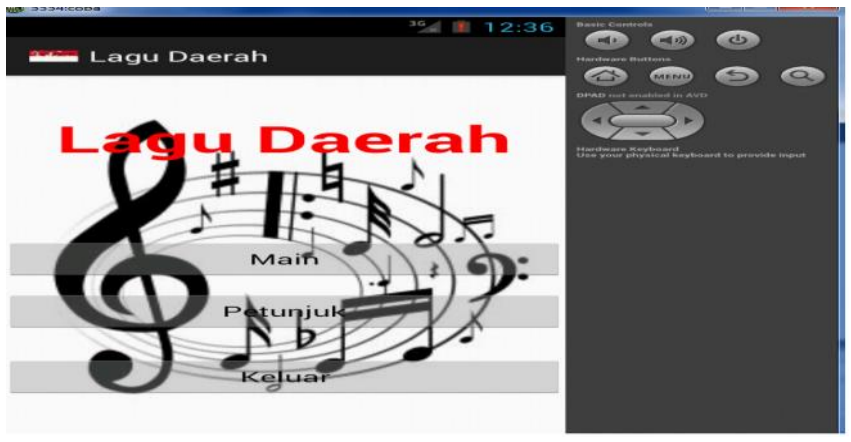

Figure 1. Display the main menu form

This name input form aims to enter the name for starting the game.

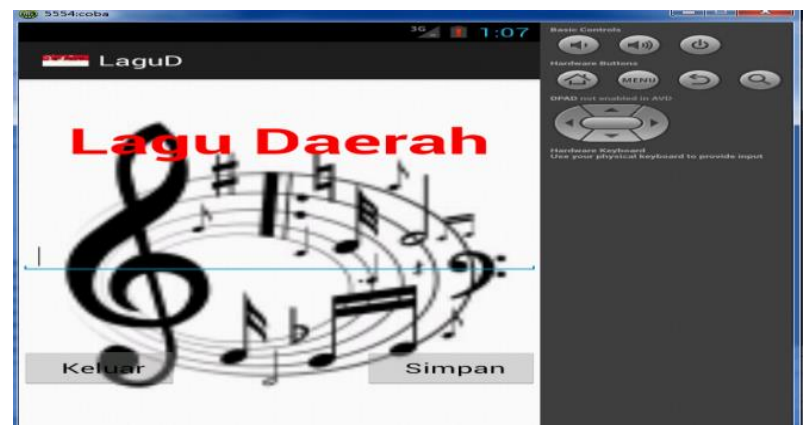

Figure 2. Display name input form

The hint form contains the game directives and rules in the game Song area.

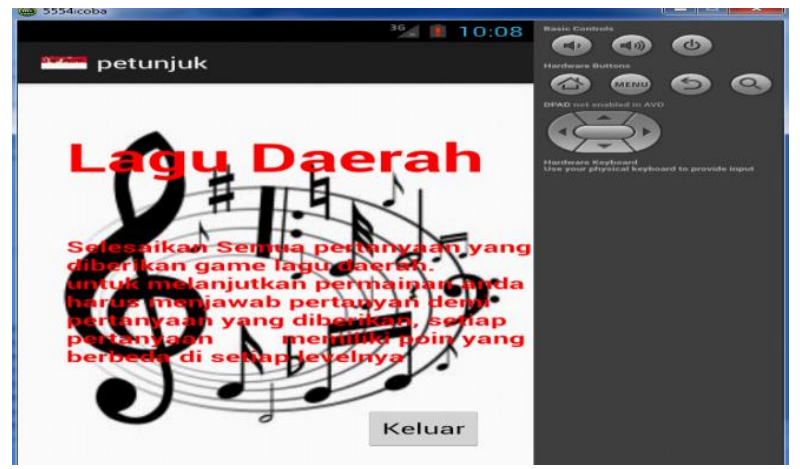

Figure 3. Display instructions form

This Game Form contains the game the player will play until it is finished.

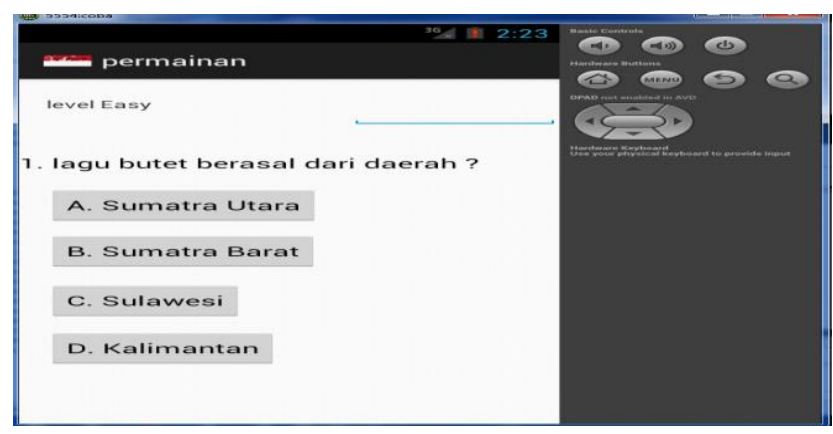

Figure 4. Display Game form 
This form is the result of a regional song game that contains points from all players

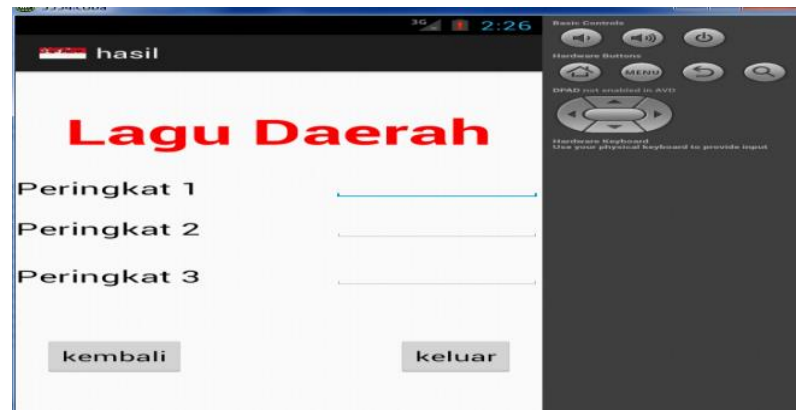

Figure 5. Display Game form

\section{CONCLUSION}

After conducting the discussion above, the authors draw the following conclusions:

1. Determination of questions and answers taken from books relating to the game Regional Songs.

2. Questions and input into the database, so that applications that are built more easily to read questions and adjust answers from players.

3. New Ranking 1 game application is designed and created to attract players' interests and enhance player knowledge, as well as to get used to interacting with computers.

4. The application of the Linear Congruent Method (LCM) can simplify the process of randomizing questions and prevent the occurrence of the same questions in the Regional Song game.

\section{REFERENCES}

[1] Muhammad Suhar, "APLIKASI GAME NEW RANGKING 1 MENGGUNAKAN METODE LINEAR CONGRUENT METHOD (LCM)," Pelita Informatika Budi Darma, vol. 16, no. (1), pp. 82-88, Agustus 2013.

[1] Edy Mulyanto, Vincent Suhartono (UDINUS) T.Sutojo, KECERDASAN BUATAN. Yogyakarta: andi, 2011.

[2] Galih Hermawan2 Aditya Galang Mahafi1, "GAME EDUKASI PENYAKIT MALARIA DAN CARA PENCEGAHANNYA," Jurnal Ilmiah Komputer dan Informatika (KOMPUTA), vol. 2, no. (1), pp. 19-26, Oktober 2013.

[3] Hanif Al Fatta 2) Singgih Yulianto 1), "RANCANG BANGUN APLIKASI GAME “THE BURGER'S ERRAND” MENGGUNAKAN ADOBE FLASH CS3," JURNAL DASI, vol. 12, no. (2), pp. 83-86, Juni 2012.

[4] Kurniawan Teguh Martono, "PENGEMBANGAN GAME DENGAN MENGGUNAKAN GAME ENGINE GAME MAKER," JURNAL SISTEM KOMPUTER, vol. 5, no. 1, pp. 23-30, Mei 2015.

[5] Tifla Khaira, Kumpulan Lagu Daerah Nusantara Terlengkap. Yogyakarta: DariMizan, 2009.

[6] Jogiyanto Hartono, Analisis dan Disain Sistem Informasi. Yogyakarta: Andi, 1990.

[7] M. Shalahuddin, M Rosa A.S, Rekayasa Perangkat Lunak Terstruktur Dan Berorientasi Objek. Bandung: Informatika, 2013.

[8] Adi Nugroho, Rekayasa Perangkat Linak. Yogyakarta: Ando, 2010.

[9] Nazruddin Safaat H, Android Pemrograman Aplikasi Mobile Smartphone. Bandung: Informatika Bandung, 2012. 